\title{
Effect of packaging materials on quality of fish protein concentrate extracted from ribbon fish, Lepturacanthus savala (Cuvier, 1829)
}

\author{
- J.M. KOLI ${ }^{1 *}$, A.R. AKHADE ${ }^{2}$ AND R.R. AKHADE ${ }^{2}$ \\ ${ }^{1}$ Post Graduate Institute-Post Harvest Management, Killa-Roha, RAIGAD (M.S.) INDIA \\ ${ }^{2}$ College of Fisheries, Shirgaon, RATNAGIRI (M.S.) INDIA \\ Email:jmkoli@gmail.com
}

*Author for Correspondence

Research chronicle : Received : 08.09.2016; Revised : 10.10.2016; Accepted : 12.11.2016

SUMMARY :

Fish protein concentrate (FPC) is a healthy and highly nutritive product produced hygienically from fishes in which, protein and other nutrients are more concentrated than fresh fishes. In the present study an attempt was made to study the functional properties of FPC derived from ribbon fish, Lepturacanthus savala were investigated in HDPE packaging materials and their shelf-life. The changes in chemical analysis of FPC powder prepared by Canadian process and stored at room temperature were investigated. Moisture content was increased in the range from 10.78 to 12.72 per cent, whereas the ash content was decreased in the range from 1.87 to 1.08 per cent, protein content was decreased in the range from 86.80 to 83.04 per cent and also, the fat content was decreased in the range from 0.55 to 0.40 per cent during the storage period of 180 days. The changes in functional properties of FPC powder prepared by Canadian process stored at room temperature were also investigated. The viscosity was decreased in the range from 114.00 to $100.00 \mathrm{cP}$; solubility was decreased in the range from 88.92 to 83.78 per cemt, emulsification capacity was decreased in the range from 67.66 to 65.08 per cent, emulsification stability was decreased in the range from 58.84 to 56.02 per cent foaming capacity was decreased in the range from 42.50 to 32.64 per cent foaming stability was decreased in the range from 26.50 to 22.56 per cent gelation was decreased in the range from 26.50 to $20.25 \mathrm{~g}$. $\mathrm{cm}$ and also, the water holding capacity was decreased in the range from 4.27 to $3.86 \mathrm{ml} / \mathrm{g}$ during the storage period of 180 days. The TPC (Total Plate Count) of the FPC powder showed increasing trend throughout the shelf-life study. The TPC of the FPC powder in storage at ambient temperature was increased from $0.42 \times 10^{2}$ to $1.48 \times 10^{3} \mathrm{cfu} / \mathrm{g}$. As per microbiological quality of FPC extracted from ribbon fish, TPC value was within the acceptable limit during storage period of 180 days. The sensory qualities of FPC powder during storage at ambient temperature for 180 days were observed. For the FPC powder gradual reduction in the scores were observed with increase in the storage period. But, during storage period the sensory evaluation score indicated that the FPC extracted from ribbon fish was within the acceptable limit.

KEY WORDS : Ribbon fish, Fish protein concentrate, Functional properties, Packaging materials

How to cite this paper : Koli, J.M., Akhade, A.R. and Akhade, R.R. (2016). Effect of packaging materials on quality of fish protein concentrate extracted from ribbon fish, Lepturacanthus savala (Cuvier, 1829). Internat. J. Proc. \& Post Harvest Technol., 7 (2) : 189-198. DOI: 10.15740/HAS/IJPPHT/7.2/189-198. 